\title{
Pengaruh Penanaman Modal Asing, Penanaman Modal Dalam Negeri Dan Belanja Modal Terhadap Pertumbuhan Ekonomi Provinsi Di Indonesia
}

\author{
Reza Lainatul Rizky ${ }^{1}$, Grisvia Agustin ${ }^{2}$, Imam Mukhlis ${ }^{3}$ \\ Jurusan Ekonomi Fakultas Ekonomi Universitas Negeri Malang \\ Email: lilianariz@yahoo.co.id
}

\begin{abstract}
This study is aimed to investigate the influence of foreign direct investments, domestic direct investments, and capital expenditures towards the Indonesia economic growth 2010-2013. Quantitative research design was employed in this study. The data used are secondary data with panel data. Panel data utilized cross section data comprising 33 provinces in Indonesia while the use of time series data in 2010-2013. The analysis method applied was panel regression analysis method with a Fixed Effect model. The result of this study demonstrated foreign direct investments, domestic direct investments, and capital expenditures have positive and significant influences towards provincial economic growth in Indonesia from the year 2010-2013 partially and simultaneously.
\end{abstract}

Keywords: Foreign Direct Investment, Domestic Direct Investment, Capital Expenditure, Economic Growth

\section{PENDAHULUAN}

Menurut Mankiw (2007: 182) pertumbuhan ekonomi merupakan indikator untuk mengetahui seberapa besar keberhasilan pembangunan ekonomi suatu negara dan sebagai penentu adanya kebijakan pembangunan selanjutnya. Suatu negara dapat dikatakan mengalami pertumbuhan ekonomi apabila terjadi kenaikan pendapatan nasional dan peningkatan output. Kenaikan pendapatan nasional ini dapat dilihat dari besarnya jumlah Produk Domestik Bruto (PDB) yang dihasilkan setiap tahun. Bagi suatu daerah untuk melihat pendapatan daerahnya dilihat dari jumlah Produk Domestik Regional Bruto (PDRB) yang dihasilkan setiap tahun. Indonesia sebagai negara berkembang memiliki karakter yang tidak berbeda jauh dengan negara berkembang lainnya, untuk mencapai pertumbuhan ekonomi Indonesia dalam proses pembangunannya dihadapkan dengan keterbatasan modal untuk investasi pembangunan Mukhlis (2015: 122). Sedangkan menurut Todaro (2006: 92) salah satu komponen utama dalam pertumbuhan ekonomi dari setiap negara adalah akumulasi modal.

Penanaman modal merupakan langkah awal untuk melakukan pembangunan. Penanaman modal yang berasal dari dalam negeri yang disebut Penanaman Modal Dalam Negeri (PMDN) dan penanaman modal yang berasal dari luar negeri yang disebut Penanaman Modal Asing (PMA). Keduanya sama penting dan berpengaruh terhadap pertumbuhan ekonomi suatu negara Dumairy (1996: 130). Tidak hanya pihak swasta yang berupaya dalam melakukan penanaman modal tetapi pemerintah juga ikut berperan. Misalnya saja pemerintah melakukan perbaikan infrastruktur dan melakukan penambahan aset. Pembiayaan pembangunan daerah untuk infrastruktur ini biasanya disebut dengan belanja modal. Belanja modal merupakan pengeluaran yang berkaitan dengan kegiatan 
investasi yang dilaksanakan oleh pemerintah untuk mencapai sasaran pembangunan. Belanja modal akan menghasilkan penyediaan sarana dan prasarana yang dibutuhkan untuk meningkatkan pertumbuhan ekonomi.

\section{KAJIAN PUSTAKA \\ Pertumbuhan Ekonomi}

Suatu wilayah dapat dikatakan mengalami pertumbuhan ekonomi yang cepat apabila dari tahun ke tahun mengalami kenaikan yang signifikan, sedangkan pertumbuhan yang lambat terjadi apabila dari tahun ke tahun mengalami penurunan atau fluktuatif. Hal ini dapat dibandingkan dengan pertumbuhan ekonomi tahun sebelumnya suatu wilayah tersebut atau membandingkannya dengan wilayah lain. Pertumbuhan ekonomi dapat diketahui dengan membandingkan PDB pada satu tahun tertentu dengan tahun sebelumnya. Berikut adalah cara menghitung laju pertumbuhan ekonomi (Sukirno, 2006).

Dimana:

$$
\text { Laju Pertumbuhan Ekonomi }(\Delta \mathrm{Y})=\frac{\mathrm{PDB}_{\mathrm{t}}-\mathrm{PDB}_{\mathrm{t}-1}}{\mathrm{PDB}_{\mathrm{t}}} \times 100
$$

$\Delta \mathrm{Y} \quad=$ laju pertumbuhan ekonomi atas dasar perubahan PDB $(\%)$

$\mathrm{PDB}_{\mathrm{t}} \quad=$ nilai PDB tahun $\mathrm{t}$

$\mathrm{PDB}_{\mathrm{t}-1} \quad=$ nilai $\mathrm{PDB}$ tahun sebelumnya

\section{Teori Pertumbuhan Ekonomi}

\section{Teori Pertumbuhan Ekonomi Klasik}

Tokoh yang mengembangkan teori pertumbuhan ekonomi klasik yaitu Adam Smith dan David Ricardo. Menurut Arsyad (1999), Adam Smith merupakan orang yang pertama membahas pertumbuhan ekonomi secara sistematis. Adam Smith mengemukakan tentang proses pertumbuhan ekonomi dalam jangka panjang secara sistematis serta aspek utama pertumbuhan ekonomi yaitu pertumbuhan output total dan pertumbuhan penduduk dalam bukunya An Inquiry Into the Nature and Causes of The Wealth of Nations (1976).

Menurut Suparmoko (2002), Adam Smith dalam perkembangan ekonomi diperlukan adanya spesialisasi dan pembagian kerja. Spesialisasi dan pembagian kerja ini bisa menghasilkan output, karena dapat meningkatkan ketrampilan dan kemampuan setiap pekerja dalam bidangnya. Pembagian kerja dapat mengurangi waktu yang hilang pada saat peralihan macam pekerjaan, serta mendorong ditemukannya alat-alat atau mesin-mesin baru yang akhirnya mempercepat dan meningkatkan produksi. Adanya pembagian kerja juga harus diseimbangi dengan akumulasi modal yang berasal dari dana tabungan. Disamping itu, perluasan juga perlu dilakukan agar dapat menampung hasil produksi. Perluasan pasar juga dapat dilakukan dengan perdagangan internasional. Hal ini akan menambah luasnya pasar, sehingga pasar akan terdiri dari pasar dalam negeri dan pasar luar negeri. Jika perluasan pasar, akumulasi modal dan pembagian kerja telah mencukupi hal ini akan menaikkan tingkat produktivitas tenaga kerja. Kenaikan produktivitas ini akan menaikkan penghasilan nasional. Jika penghasilan nasional meningkat maka kesejahteraan juga meningkat hal ini menyebabkan pertambahan jumlah penduduk.

David Ricardo juga menjadi pemikir yang paling menonjol dalam aliran Klasik. Teori yang dikembangkan Ricardo dalam bukunya The Principles of 
Political Economy and Taxation yang diterbitkan pada tahun 1917 menyangkut empat kelompok permasalahan sebagai berikut (Arsyad, 1999).

1) Teori tentang nilai dan harga barang.

2) Teori tentang distribusi pendapatan sebagai pembagian hasil dari seluruh produksi dan disajikan dalam bentuk teori upah, teori sewa tanah, teori bunga dan laba.

3) Teori tentang perdagangan internasional.

4) Teori tentang akumulasi dan pertumbuhan ekonomi.

\section{Teori Pertumbuhan Ekonomi Harrod-Domar}

Teori pertumbuhan Harrod-Domar ini dikembangkan oleh dua ekonom yaitu Evsey Domar dan R.F. Harrod. Domar. Harror mengemukakan teorinya tersebut pertama kali pada tahun 1947 dalam jurnal A American Economic Review, sedangkan Harrod telah mengemukakannya pada tahun 1939 dalam Economic Journal. Menurut Sukirno (2006: 33), teori pertumbuhan ekonomi Harrod-Domar bertujuan untuk menerangkan syarat-syarat yang harus dipenuhi supaya suatu perekonomian dapat mencapai pertumbuhan dalam jangka panjang. Dengan menggunakan pemisalan-pemisalan seperti barang modal telah mencapai kapasitas penuh, tabungan adalah proposional dengan pendapatan nasional, rasio modalproduksi (capital-output ratio) tetap nilainya, dan perekonomian terdiri dari dua sektor.

Menurut Jhingan (2003: 229), Harrod dan Domar memberikan peranan kunci kepada investasi di dalam proses pertumbuhan ekonomi. Pertama menciptakan pendapatan sebagai dampak permintaan, dan memperbesar kapasitas produksi perekonomian dengan cara meningkatkan stok modal sebagai dampak penawaran. Karena itu, selama investasi tetap berlangsung, pendapatan nyata dan output akan senantiasa membesar. Namun demikian untuk mempertahankan tingkat ekuilibrium pendapatan pada pekerjaan penuh dari tahun ke tahun, baik pendapatan nyata maupun output tersebut keduanya harus meningkat dalam laju yang sama pada saat kapasitas produktif modal meningkat.

Dalam teori Harrod-Domar, untuk menumbuhkan suatu perekonomian diperlukan pembentukan modal sebagai tambahan stok modal. Pembentukan modal tersebut dipandang sebagai pengeluaran yang akan menambah kesanggupan suatu perekonomian untuk menghasilkan barang-barang maupun sebagai pengeluaran yang akan menambah permintaan efektif seluruh masyarakat. Inti dari teori HarrodDomar yaitu, setiap perekonomian dapat menyisihkan suatu proporsi tertentu dari pendapatan nasionalnya jika hanya untuk menganti barang-barang modal (gedung, peralatan, material) yang rusak. Namun demikian untuk menumbuhkan perekonomian tersebut, diperlukan investasi-investasi baru sebagai stok penambah modal (Todaro, 2006: 96).

\section{Penanaman Modal \\ Penanaman Modal Asing (PMA)}

Berdasarkan Undang-Undang Republik Indonesia Nomor 25 Tahun 2007 dalam Pasal 1 Ayat 9 Tentang Penanaman Modal, penanaman modal asing adalah kegiatan menanam modal untuk melakukan usaha di wilayah negara Republik Indonesia yang dilakukan oleh penanam modal asing, baik yang menggunakan modal asing sepenuhnya maupun yang berpatungan dengan penanam modal dalam negeri. 
Menurut Salim dan Budi (2008: 149) penanaman modal asing merupakan transfer modal baik nyata maupun tidak nyata dari suatu negara ke negara lain atau pemindahan modal. Tujuan pemindahan modal ini digunakan di negara tersebut agar menghasilkan keuntungan dibawah pengawasan dari pemilik modal, baik total maupun sebagian.

\section{Penanaman Modal Dalam Negeri (PMDN)}

Berdasarkan Undang-Undang No. 25 Tahun 2007 tentang Penanaman Modal Pasal 1 Ayat 2 menyebutkan bahwa Penanaman Modal Dalam Negeri adalah Kegiatan menanam modal untuk melakukan usaha di wilayah Negara Republik Indonesia yang dilakukan oleh penanam dalam negeri dengan menggunakan modal dalam negeri.

\section{Belanja Modal dalam Anggaran Pendapatan dan Belanja Daerah (APBD)}

APDB merupakan salah satu komponen laporan keuangan daerah. Struktur APBD menurut Kepmendagri No. 29 Tahun 2002 merupakan satu kesatuan yang terdiri dari atas pendapatan daerah, belanja daerah, dan pembiayaan. Stuktur APBD diklasifikasikan berdasarkan bidang pemerintahan daerah yang disesuaikan dengan macam dan jenis kewenangan yang dimiliki oleh daerah.

Belanja modal digunakan untuk pengeluaran yang dilakukan untuk pembangunan aset tetap berwujud yang mempunyai nilai manfaat lebih dari dua belas bulan untuk digunakan dalam kegiatan pemerintahan. Berikut adalah yang termasuk dalam belanja modal (Yuwono, dkk, 2008: 101).

a. Tanah yang dikelompokkan sebagai asset tetap ialah tanah yang diperoleh untuk siap dipakai dalam kegiatan operasional pemerintah dan dalam kondisi siap pakai. Perolehannya dengan cara mengeluarkan biaya harga pembelian serta biaya untuk memperoleh hak, biaya yang berhubungan dengan pengukuran dan penimbunan.

b. Peralatan dan mesin merupakan mesin-mesin dan kendaraan bermotor, alat elektronik, seluruh investasi kantor, dan peralatan lain yang nilainya signifikan dan masa manfaatnya lebih dari dua belas bulan serta dalam kondisi siap pakai. Hal-hal yang mengubah nilai peralatan dan mesin adalah penambahan, pengurangan, pengembangan dan penggantian utama. Dalam pencatatannya harus dibuat ketentuan yang berbeda antara hal-hal yang mengubah nilai tersebut.

c. Gedung dan bangunan yaitu mencakup seluruh gedung dan bangunan yang diperoleh untuk dipakai dalam kegiatan operasional pemerintah dan dalam kondisi siap pakai. Hal-hal yang mengubah nilai gedung dan bangunan adalah penambahan, pengurangan, pengembangan dan penggantian utama.

d. Jalan, irigasi dan jaringan yaitu asset yang dimiliki atau dikuasai pemerintah berupa jalan, irigasi, dan jaringan dalam keadaan siap pakai.

e. Aset tetap lainnya yaitu mencakup aset tetap yang tidak dapat dikelompokkan kedalam kelompok aset tetap yang telah disebutkan diatas, yang diperoleh dan dimanfaatkan untuk kegiatan operasional pemerintah kedalam kondisi siap pakai dengan masa manfaat lebih dari satu periode akuntansi. Aset tetap lainnya dapat diperoleh dari dana yang bersumber dari sebagian atau seluruh APBD melalui pembelian, pembangunan, hibah atau donasi, pertukaran dengan aset lain dan dari sitaan atau rampasan. 


\section{METODE}

Penelitian ini adalah menggunakan metode pendekatan kuantitatif. Jenis data yang digunakan dalam penelitian ini adalah data sekunder. Metode analisis yang digunakan dalam penelitian ini adalah analisis regresi berganda dengan data panel menggunakan data cross section dengan 33 provinsi di Indonesia dan data time series periode tahun 2010-2013. Berikut merupakan model analisis regresi data panel yang digunakan dalam penelitian ini.

Keterangan:

$$
Y_{i t}=\beta_{0}+\beta_{1} X_{1 i t}+\beta_{2} X_{2 i t}+\beta_{3} X_{3 i t}+e_{i t}
$$

$\mathrm{Y}=$ Pertumbuhan Ekonomi

$\beta_{0}=$ Intersep

$\mathrm{X}_{1}=$ Penanaman Modal Asing

$\mathrm{X}_{2}=$ Penanaman Modal Dalam Negeri

$\mathrm{X}_{3}=$ Belanja Modal

$\beta_{1}=$ Koefisien regresi variabel Penanaman Modal Asing

$\beta_{2}=$ Koefisien regresi variabel Penanaman Modal Dalam Negeri

$\beta_{3}=$ Koefisien regresi variabel Belanja Modal

$\mathrm{e}=$ Variabel gangguan atau kesalahan (disturbancelerror terms)

$\mathrm{i}=$ Unit cross section propinsi di Indonesia

$\mathrm{t}=$ Unit time series tahun 2010-2013

Menurut Widarjono (2013:355) terdapat tiga pendekatan yang dapat digunakan untuk mengestimasi model regresi dengan data panel. Yaitu sebagai berikut: (1) Pooled Least Square (PLS) metode ini mengestimasi data panel dengan metode Ordinary Least Square $(O L S)$. Pendekatan PLS ini secara sederhana menggabungkan (pooled) seluruh data runtun waktu dan antar ruang, serta berasumsi bahwa baik intercept dan slope dianggap sama untuk tiap waktu dan individu. Metode ini tidak memperhatikan dimensi individu maupun waktu. (2) Fixed Effect (FE) merupakan model yang mengasumsikan adanya perbedaan intersep antar individu tetapi slope tetap. Metode ini menambahkan veriabel dummy untuk menangkap adanya perbedaan intersep. (c) Random Effect (RE) model ini akan mengestimasi data panel dimana variabel gangguan mungkin saling berhubungan antar waktu dan antar individu. Pendekatan Random Effect memperbaiki efisiensi proses least square dengan memperhitungkan error dari antar ruang dan runtun waktu dengan variabel gangguan (error term).

Menurut Widarjono (2013:363) untuk menentukan apakah model panel data dapat diregresi dengan metode Pooled Least Square (PLS), metode Fixed Effect (FE) atau metode Random Effect (RE), maka dilakukan uji sebagai berikut: (1) Uji Chow dapat digunakan untuk memilih teknik dengan metode pendekatan Common Effect atau Pooled Least Square (PLS) atau metode Fixed Effet (FE). (2) Uji Hausman digunakan untuk memilih antara metode pendekatan Fixed Effect (FE) atau Random Effect (RE).

\section{HASIL DAN PEMBAHASAN}

Hasil penelitian ini menunjukkan bahwa secara parsial penanaman modal asing berpengaruh positif dan signifikan terhadap pertumbuhan ekonomi provinsi di Indonesia tahun 2010-2013. Hal ini berarti apabila nilai penanaman modal asing mengalami peningkatan maka pertumbuhan ekonomi juga akan meningkat karena memiliki pengaruh yang positif. Nilai penanaman modal asing 33 provinsi di 
Indonesia memiliki pengaruh yang positif dan signifikan terhadap pertumbuhan ekonomi di Indonesia karena didorong oleh beberapa hal, yaitu perekonomian Indonesia yang sehat, stabilitas politik, iklim investasi di Indonesia, infrastruktur di Indonesia, sumber daya alam yang melimpah, keadaan demograf, adanya pasar domesik dan peran global Indonesia.

Penanaman modal asing pada penelitian ini merupakan penanaman modal asing pada sektor riil di Indonesia yang bergerak pada bidang industri manufaktur sehingga penanaman modal asing pada bidang industri manufaktur akan meningkatkan pertumbuhan ekonomi di Indonesia. Hal ini terjadi karena aliran penanaman modal asing pada bidang industri manufaktur akan menghasilkan eksternalitas dalam bentuk transfer teknologi dan spillover (Mukhlis, 2012).

Hasil penelitian teori pertumbuhan ekonomi aliran klasik, teori pertumbuhan ekonomi Harrod dan Domar yang menyatakan bahwa investasi merupakan kunci di dalam proses pertumbuhan ekonomi dan untuk menumbuhkan suatu perekonomian diperlukan investasi sebagai tambahan stok modal. Serta sejalan dengan penelitian yang telah dilakukan Elvany Noor Afia (2010).

Hasil lain dalam penelitian bahwa secara parsial penanaman modal dalam negeri berpengaruh positif dan signifikan terhadap pertumbuhan ekonomi provinsi di Indonesia tahun 2010-2013. Hal ini berarti apabila nilai penanaman modal asing mengalami peningkatan maka pertumbuhan ekonomi juga akan meningkat karena memiliki pengaruh yang positif.

Nilai penanaman modal dalam negeri 33 provinsi di Indonesia memiliki pengaruh yang positif dan signifikan terhadap pertumbuhan ekonomi di Indonesia karena didorong oleh beberapa hal yaitu yang pertama yaitu iklim investasi di Indonesia, infrastruktur di Indonesia, sumber daya alam melimpah, dan adanya pasar domesik. Penanaman modal dalam negeri pada penelitian ini merupakan penanaman modal dalam negeri pada sektor riil di Indonesia di luar sektor minyak dan gas bumi, maka akan difokuskan untuk sektor primer, sekunder dan tersier di luar sektor minyak dan bumi.

Hasil penelitian teori pertumbuhan ekonomi aliran klasik, teori pertumbuhan ekonomi Harrod dan Domar yang menyatakan bahwa investasi merupakan kunci di dalam proses pertumbuhan ekonomi dan untuk menumbuhkan suatu perekonomian diperlukan investasi sebagai tambahan stok modal. Serta sejalan dengan penelitian yang telah dilakukan oleh Elvany Noor Afia (2010) dan Eko Prasetyo (2011).

Berkaitan belanja modal dan pertumbuhan ekonomi, diperoleh hasil bahwa secara parsial belanja modal berpengaruh positif dan signifikan terhadap pertumbuhan ekonomi provinsi di Indonesia tahun 2010-2013. Hal ini berarti apabila nilai belanja modal mengalami peningkatan maka pertumbuhan ekonomi juga akan meningkat karena memiliki pengaruh yang positif.

Belanja modal memiliki pengaruh terhadap pertumbuhan ekonomi dikarenakan realisasi belanja modal pemerintah dilaksanakan dengan baik dalam pembangunan infrastruktur publik. Pemerintah memperhatikan pengelolaan belanja modal dengan baik untuk menunjang investasi dalam mendorong pertumbuhan ekonomi 33 provinsi di Indonesia. Pemerintah melakukan evaluasi dan pengkajian terhadap barang-barang inventaris yang tersedia baik dari sisi kondisi maupun umur ekonomisnya sehingga pengadaan barang inventaris dapat dilakukan secara selektif sesuai kebutuhan masing-masing wilayah. 


\section{KESIMPULAN}

Berdasarkan pengujian dan analisis yang telah dilakukan, maka dapat ditarik kesimpulan dalam penelitian ini adalah sebagai berikut. a) Penanaman modal asing mempengaruhi pertumbuhan ekonomi 33 provinsi di Indonesia. Maka semakin tinggi nilai penanaman modal asing maka semakin tinggi pula pertumbuhan ekonomi. b) Penanaman modal dalam negeri mempengaruhi pertumbuhan ekonomi 33 provinsi di Indonesia. Maka semakin tinggi nilai penanaman modal dalam negeri maka semakin tinggi pula pertumbuhan ekonomi. c) Belanja Modal mempengaruhi pertumbuhan ekonomi 33 provinsi di Indonesia serta berdasarkan hasil penelitian penanaman modal asing, penanaman modal dalam negeri dan belanja modal mempengaruhi pertumbuhan ekonomi 33 provinsi di Indonesia.

Hasil dari penelitian ini diharapkan dapat dijadikan dasar pertimbangan, perbaikan maupun peningkatan dalam menentukan arah kebijakan yang berhubungan dalam penanaman modal. Misalnya saja untuk peningkatan penanaman modal asing dan penanaman modal dalam negeri, pemerintah pusat Indonesia membuat kebijakan untuk menjamin kelangsungan iklim investasi yang kondusif bagi investor asing dan domestik di Indonesia. Pemerintah sebaiknya mempermudah perizinan untuk berinvestasi di Indonesia dan pemerintah harus mengarahkan penanaman modal asing tidak hanya untuk badan usaha besar tetapi untuk usaha kecil mikro dan menegah di Indonesia yang masih banyak kekurangan modal. Untuk pemerintah daerah sebaiknya melakukan promosi mengenai potensi ekonomi regional yang dimiliki masing-masing provinsi agar menarik investor asing untuk menanamkan modalnya.

\section{Daftar Rujukan}

Arsyad, Lincolin. 1999. Ekonomi Pembangunan Edisi keempat. Yogyakarta: STIE YKPN.

Dumairy. 1996. Perekonomian Indonesia. Jakarta: Erlangga.

Jhingan, M.L. 2003. Ekonomi Pembangunan. Jakarta: Erlangga.

Keputusan Menteri Dalam Negeri Nomor 29 Tahun 2002 Tentang Pedoman Pengurusan, Pertanggungjawaban dan Pengawasan Keuangan Daerah Serta Tata Cara Penyusunan Anggaran Pendapatan Belanja Daerah, Pelaksanaan Tata Usaha Keuangan Daerah dan Penyusunan Perhitungan Anggaran Pendapatan dan Belanja Daerah. (Online), (http://hukum.unsrat.ac.id/men/ mendagri_29_2002.pdf), diakses tanggal 06 Agustus 2015.

Mankiw, N. Gregory. 2007. Makro Ekonomi Edisi keenam. Jakarta: Erlangga.

Mukhlis, Imam. 2012. Ekonomi Internasional Indonesia Dalam Perspektif Teoritis dan Empiris. Tulungagung: Cahaya Abadi.

Mukhlis, Imam. 2015. Ekonomi Keuangan dan Perbankan Teori dan Aplikasi. Jakarta: Salemba Empat.

Noor Afia, Elvany. 2010. Pengaruh Penanaman Modal Asing (PMA), Penanaman Modal Dalam Negeri (PMDN) dan Belanja Modal Terhadap Produk Domestik Regional Bruto (PDRB) Provinsi Jawa Tengah. (Online). (http://core.ac.uk/download/pdf/11722164.pdf), diakses tanggal 06 Agustus 2015.

Prasetyo, Eko. 2011. Analisis Pengaruh Penanaman Modal Dalam Negeri (PMDN), Penanaman Modal Asing (PMA), Tenaga Kerja, Dan Ekspor Terhadap Pertumbuhan Ekonomi Di Jawa Tengah Periode Tahun 1985 - 
2009. (Online). (http://lib.unnes.ac.id/7870/1/10322.pdf), diakses tanggal 10 Agustus 2015.

Salim H.S., S.H., M.S. dan Budi Sutrisno, S.H., M.Hum. 2008. Hukum Investasi di Indonesia. Jakarta: Grafindo Persada.

Sukirno, Sadono. 2006. Makroekonomi Teori Pengantar. Jakarta: PT Rajagrafindo Persada.

Suparmoko. 2002. Pengantar Ekonomi Makro: Teori, Soal dan Penyelesaiannya. Yogyakarta: UPP AMP YKPN.

Todaro, Michael P. 2006. Pembangunan Ekonomi di Dunia ketiga, Edisi 9, Jilid 1. Jakarta: Erlangga. Alih Bahasa Drs. Haris Munandar.

Undang-Undang Republik Indonesia Nomor 25 Tahun 2007 Tentang Penanaman Modal (Online), (http://www.bi.go.id/id/tentang-bi/uu-bi/Documents/UU25 Tahun 2007 Penanaman Modal.pdf), diakses tanggal 05 Agustus 2015.

Widarjono, Agus.2013. Ekonometrika Pengantar dan Aplikasinya. UPP STIM YKPN, Yogyakarta.

Yuwono, Sony, dkk. 2008. Memahami APBD dan Permasalahannya "Panduan Pengelolaan Keuangan Daerah". Malang: Bayumedia.

Zaris, Roeslan. 1987. Prespektif Daerah dalam Pembangunan Nasional. Jakarta: LPFE UI Jakarta. 